\title{
Effect of Pomegranate Molasses on Egg Quality Traits During Different Storage Time in Laying Hens
}

\author{
İ.Sadi ÇETİNGÜL, Aamir IQBAL*, İsmail BAYRAM, Eyüp Eren GÜLTEPE, \\ Cangir UYARLAR, Ümit ÖZÇINAR \\ Department of Animal Nutrition and Nutritional Diseases, Faculty of Veterinary Medicine, Afyon Kocatepe University, 03030 \\ Afyonkarabisar, Turkey.
}

\begin{abstract}
The present study trial was conducted to investigate the effects of pomegranate molasses on egg quality at different storage periods. A total of 240 Babcock white laying hens (58 weeks old) were divided into 5 groups $(n=48)$ with 8 subgroups having 6 hens in each. Pomegranate molasses was added in the drinking water to experimental groups with $0 \%, 0.1 \%, 0.25 \%, 0.5 \%$, and $1 \%$, respectively during 4 weeks. At the end of study (30 days), total of 320 eggs were collected randomly and eighty eggs (80) were analyzed at 0 day of storage while other eggs were stored at $4^{\circ} \mathrm{C}$ temperature for 10,20 and 30 days. The result reveals that the egg weight, egg shell thickness and albumin index remained non-significant $(\mathrm{P}>0.05)$ during the whole trial Moreover, Haught unit showed positive response in the group $\mathrm{B}$ and $\mathrm{D}$ at 10 day storage as compared with control group however, it was remained non-significant $(\mathrm{P}<0.05)$ at 0,20 and 30 days of storage. It is concluded that pomgranate mollases has shown positive effect on some egg quality traits during several storage periods $0,10,20,30$ days.
\end{abstract}

Keywords: Laying hens, pomgranate mollases, Egg storage, Egg quality triats

\section{Yumurta Tavuklarında Nar Ekşisinin Yumurtaların Farklı Depolama Sürelerinde Yumurta Kalitesi Üzerine Etkisi}

\section{ÖZ}

Bu araştırma, yumurta tavuklarında içme suyuna katılan nar ekşisinin, 0, 10, 20 ve 30 günlük sürelerle depolanan yumurtaların bazı kalite özelliklerine etkisini belirlemek amacıyla gerçekleştirilmiştir. Toplam 240 adet 58 haftalık yaşta Babcock beyaz yumurtacı tavuk her birinde 48 adet olmak üzere 5 gruba ayrılmıştır. Deneme grupları ayrıca her birinde 6 adet tavuk bulunan 8 alt gruba ayrılmıştır. Çalışmada deneme grupları içme sularına (A, B, C, D ve E) 4 hafta boyunca sirasıyla $\% 0, \% 0.1, \% 0.25, \% 0.5$ ve $\% 1$ oranlarında nar ekşisi ilave edilmiştir. Araştırmanın 30. gününde, toplam 320 yumurta gruplardan rastgele toplanmıştır. Toplanan yumurtaların 80 adedi aynı gün analiz edilirken (0. Gün), diğer yumurtalar ise $4^{\circ} \mathrm{C}$ sıcaklıkta 10,20 ve 30 gün boyunca depolanmiştır. Bu yumurtalardan 80 yumurta 10 gün sonra analiz edilirken, kalan yumurtaların 80 adedi 20. Gün, 80 adedi ise 30 günlük depolamadan sonra analiz edilmiştir. Araştırmada içme sularına nar ekşisi katılan tavukların farklı sürelerle depolanan yumurtaların ağırlıklarının gruplar arası karşılaştırmasında anlamlı farklılıklar görülmemiştir (P>0.05). İlave olarak, Haugh birimi değeri B ve D gruplarında 10 günlük depolamada kontrol grubuna kıyasla yüksek bulunmuştur. Sonuç olarak, nar ekşisinin 0, 10, 20, 30 günlük sürelerle depolama periyodunda bazı yumurta kalitesi özellikleri üzerinde olumlu etki gösterdiği sonucuna varılmıştır.

Anahtar Kelimeler: Yumurta tavuğu, Nar ekşisi, Yumurta depolama, Kalite

To cite this article: Cetingül İ.S. Iqbal A. Bayram I. Gültepe E.E. Uyarlar C. Özcmar Ü. Effect of Pomegranate Molasses on Egg Quality Traits During Different Storage Time in Laying Hens. Kocatepe Vet J. (2019) 12(2):193-199.

Submission: 12.03.2019 Accepted: 21.05.2019 Published Online: 02.06.2019

ORCID ID; İSÇ: 0000-0002-7608-6176, AI: 0000-0003-4473-2329, İB: 0000-0002-9993-7092,

EEG: 0000-0002-2404-1232, CU: 0000-0002-7803-2454, ÜÖ: 0000-0002-1143-1215

*Corresponding author e-mail: aamir_vet@yahoo.com 


\section{INTRODUCTION}

Poultry is the most important sector in livestock of any country. It is the passion of farmer to supply humankind with pure food including the meat and eggs. Poultry is the foremost widely used and cheaper source of protein. Although science contributed a lot to develop this industry, still there are some limitations in quality. Layer farmers need the better egg production in terms of egg shelf life during storage and its internal quality parameters like yolk height and width, albumin height and width, Egg shell thickness, yolk color and egg weight. The internal quality of eggs is more porn to replenish after they are laid by the layers. There are some factors like age of flock (Williams 1992), genetic factors that play a role in egg quality after storage. Not only these, but there are also some critical and value able parameters like storage time and temperature(Samli et al. 2005) that are noticed for egg quality. Egg quality change is directly related to the carbon dioxide loss through the shell pores in freshly laid eggs during storage (Scott et al. 1971). Egg quality parameters can be controlled and evaluated during different storage times by the dietary supplementation of different plant based products. The internal quality of eggs has more chances to replenish after they are laid by the layers. There is a need to focus on the use of herbs in diet to increase the quality of eggs during and after storage. Many researchers have played role in this field. Many researchers have got positive effects of herbal extracts and oils on performance parameters including egg production and quality (Rahimi et al. 2011, Khan et al. 2012).

Turkey is famous for cultivation and it comes at $4^{\text {th }}$ position all over the world (Özkal And Dinç 1993). Aril is an edible part of pomegranate and it is composed of $52 \%(\mathrm{w} / \mathrm{w})$ of the total fruit mass and $78 \%$ juice and $22 \%$ seeds. The seeds contain polyunsaturated fatty acids (PUFA), polyphones, minerals, sugars, vitamins and polysaccharides (Miguel et al. 2004). Pomegranates are studied as a phytochemical source and used as antifungal and antiviral. It decreases the impacts of paralysis, rectocele, leucorrhea, menorrhagia, colic, and dysentery (Wu et al. 2016).

Pomegranate juice contains polyphenol antioxidants (ellagic acid and punicalagin) and the antioxidant content of pomegranate juice is among the highest of any foods (Guo et al. 2004). Pomegranate juice contains cyanidin-3-O-glucoside, cyanidin-3,5-di-Oglucoside, delphinidin-3-O-glucoside, delphinidin-3,5di-O-glucoside, pelargonidin-3-O-glucoside, and pelargonidin-3,5-di-Oglucoside (Lansky et al. 1993).

Traditional methods are adapted to make pomegranate molasses. The process of its concentration is done by boiling pomegranate without adding any sugar or other additives. The procedure of processing involves cleaning, crushing, extraction, filtration, clarification and evaporation in open vessel or under vacuum. There are different type's production methods (Ezra et al. 2010, Gunal et al. 2006). The final product is highly nutritive because this is a concentrate and especially the presence of high mineral contents makes it more nutritious. The strong antioxidant activity of it is also important for egg quality and human health. It is anti-carcinogenic and due to its interaction with the process of angiogenesis, circulation, invasion, and tumor cell proliferation, its use is enhanced. Many study trials approved and conducted for the use of pomegranate juice as anti-inflammatory, antioxidant, antiatherogenic anti-carcinogenic and antimicrobial effects. Its potential against harmful effects of ultraviolet rays and cardiovascular diseases diabetics and cancer has attracted a number of researchers to investigate more (Y1lmaz and Usta 2010). Linseed oil with pomegranate juice was used in broilers for 6 weeks and examination of the adipose tissue, fatty acid profiles, blood parameters, liver enzymes, and serum profiles showed an increase in white blood cells for $0.5 \%$ and $1.0 \%$ dose group and decrease in the cholesterol level for the group being offered 1.5 $\%$ pomegranate with linseed oil (Manterys et al. 2016).

According to (Kalida and Jayanty 2010) $500 \mathrm{mg} / \mathrm{kg}$ of whole pomegranate extract was given to rats in India and anti-depressant effect was noticed in the trial. It has been published that no negative effect was seen on yield parameters after the addition of $5 \%$ and $10 \%$ levels in drinking water to chicken for one month. (Rahman et al. 2017). Pomegranate seed pulp may be used as potential feed supplement up to $5 \%$ for the laying hens and no adverse effect on egg quality and production was reported (Saki et al. 2014c).Pistacia terebinthus seeds at 20 and $40 \mathrm{~g} \quad \mathrm{~kg}-1$ supplementation levels could be used to extend the shelf life of eggs without any adverse effect on egg quality(Gultepe 2018).

Pomegranate seed oil is rich in the CLA (conjugated linolic acid) isomer known as punicic acid and it have been shown that the concentration of punicic acid in pomegranate seed oil ranges from 45 to $70 \%$. Many researchers have shown that CLA is readily incorporated into egg yolk (Windisch et al. 2008). Commercial table eggs are therefore, used as a vehicle to enhance human nutrition. Many studies have shown that the exogenous use of CLA containing feeds affects the sensory properties and shelf life of the eggs. It improves the texture of egg yolks. Manterys et al. (2016), reported that there was significant increase in the hardness of CLA enriched eggs. The textures of yolks from eggs containing CLA were rubbery and elastic and these yolks were 
relatively difficult to brake using an Instron (Ahn et al. 1999).

Keeping in view the above points, the present study was designed to investigate the effect of pomegranate molasses on egg quality traits during storage in laying hens.

\section{MATERIALS and METHODS}

The current study was performed at the Experimental Animal Research farm of Afyon Kocatepe University, Turkey after the approval of the Local Ethics Committee of the faculty of veterinary medicine under approval No: AKÜHADYEK-146-16, on 0301-2016.

\section{Experimental design and management}

The present study trial was conducted to investigate the effects of pomegranate molasses on egg quality after storage for different periods. A total of 240 Babcock white laying hens (58 weeks old) were divided into 5 groups $(n=48)$ with 8 subgroups having 6 hens in each. Pomegranate molasses was added in the drinking water to experimental groups with $0 \%, 0.1 \%, 0.25 \%, 0.5 \%$, and $1 \%$, respectively during 4 weeks. The 16 hours light and 8 hours dark period was given.In this study all treatment groups were fed the basal diet, which was prepared according to the (National Research Council 1994) recommendation to meet the bird's requirement. (Table.1.0) the diet offered was isocaloric and isonitrogenous.

POM molasses ingredients analyses were performed as a comparative examination regarding the qualitative and quantitative evaluation of phenolic compounds by HPLC in molasses obtained from pomegranate. This method has a good repeatability, since several analyses carried out on the same sample produce a repeatability coefficient of percent variation $(\mathrm{CV} \%)$ of $7 \%$, which is similar to the values reported by other Authors (Angerosa et al. 1996) (Table.2.0).

\section{Data Collection and Analyses}

Pomegranate molasses was poured in fresh drinking water on daily basis A total of 320 eggs were collected at 30th day randomly. 80 eggs were analyzed at the 0 day and remaining were stored at $4^{\circ} \mathrm{C}$ temperature for 10, 20, 30 days. 80 eggs were analyzed at 10 day and 20 eggs were analyzed after 20 days storage and 30 eggs were analyzed after the 30 day storage. The egg analysis was done at the central laboratory of the concerned university department.

\section{Statistics}

The model assumptions of normality and homogeneity of variance were examined by ShapiroWilk and Levene tests, respectively. The statistical analysis was performed with MedCalc software (MedCalc Software bvba, Ostend, Belgium, version
17.5). One-way ANOVA was used for group comparison followed by Tukey-Kramer for post-hoc. All data were expressed as mean \pm SEM. The significance level was considered as $\mathrm{p}<0.05$.

\section{RESULT}

The result of the recent study showed that there was no significant effect $(p>0.05)$ on egg weight during the whole study protocol (Table.3.0)

However, the yolk color showed positive response $(\mathrm{P}<0.05)$ in groups $\mathrm{D}$ and $\mathrm{E}$ at 30 day of storage within the groups as compared with control group. In contrast, the yolk color $(\mathrm{P}<0.05)$ decreased at 0 and 10th day of storage period between the treatment groups as compapred with control group (Table. 4.0) Haught unit showed positive response in the group $B$ and $\mathrm{D}$ at 10 day storage as compared with control group however, it was remained non-significant $(\mathrm{P}<0.05)$ at 0,20 and 30 days of storage (Table. 5.0)

Egg shell thickness remained non-significant ( $>0.05)$ during the whole trial of egg analysis. (Table. 6)

Egg Albumin index was decreased significantly within the group B that was offered $0.25 \mathrm{mg} / \mathrm{L}$ of pomegranate molasses juice however it was remained non-significant in all groups as compared with control group (Table. 7.0) A significant impact $(\mathrm{P}<0.05)$ was seen within all groups at $0,10,20,30$ day storage analysis on yolk index however, no positive effect $(\mathrm{P}<0.05)$ were observed between the groups at different storage time (Table. 8.0)

Table 1. Composition of basal diet

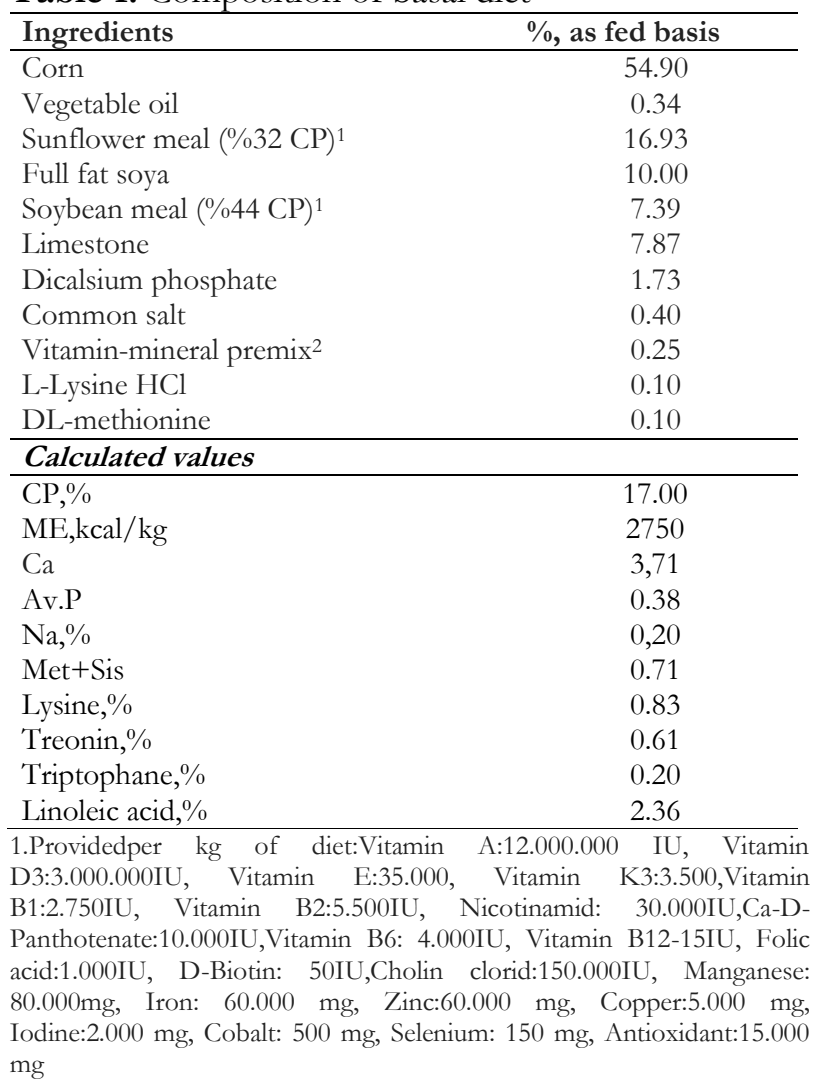


Table 2. Ingredients of Pomegranate Molasses

\begin{tabular}{ll}
\hline Caffeic (ppm) & 4240.998 \\
P-coumaric (ppm) & 0.799 \\
Cinnamic (ppm) & 5.338 \\
2,5 dihydrokci (ppm) & 819.052 \\
Epicatechin (ppm) & 1356.114 \\
Ellagic (ppm) & 883.340 \\
Acetic acid (ppm) & 273.60 \\
Propoinic acid (ppm) & 624.72 \\
Butyric acid (ppm) & 5417.97 \\
\hline
\end{tabular}

Composition of Molasses (Anonymous, 2001) Amount

Water Soluble Dry Matter, \%, minimum

Titration acidity (as citric acid), \%, minimum

$\mathrm{PH}$

3.0

HMF, mg/100g, maximum

50

Table 3. Effect of Pomegranate molasses on egg weight at 0,10,20 and 30 days of storage

\begin{tabular}{|c|c|c|c|c|c|c|c|c|c|}
\hline \multirow[t]{2}{*}{ Group } & \multicolumn{2}{|c|}{$0^{\text {th }} \mathrm{day}$} & \multicolumn{2}{|c|}{$10^{\text {th }}$ day } & \multicolumn{2}{|c|}{$20^{\text {th }}$ day } & \multicolumn{2}{|c|}{$30^{\text {th }}$ day } & \multirow[t]{2}{*}{$\mathrm{p}$} \\
\hline & $\overline{\bar{X}}$ & SEM & $\overline{\bar{X}}$ & SEM & $\overline{\bar{X}}$ & SEM & $\overline{\bar{X}}$ & SEM & \\
\hline A & 67.991 & 1.4814 & 66.390 & 1.4364 & 69.089 & 1.8174 & 66.670 & 1.4408 & 0.578 \\
\hline B & 65.704 & 1.9121 & 65.723 & 1.6124 & 65.733 & 1.5049 & 67.216 & 1.5188 & 0.887 \\
\hline C & 66.684 & 1.8620 & 67.505 & 2.0790 & 65.704 & 1.9736 & 64.489 & 1.8607 & 0.692 \\
\hline D & 68.809 & 1.4948 & 62.675 & 1.5095 & 66.643 & 1.5735 & 66.899 & 1.7489 & 0.380 \\
\hline E & 68.904 & 1.0693 & 65.636 & 1.5709 & 65.063 & 1.3452 & 65.638 & 1.4265 & 0.225 \\
\hline$P$ & & 774 & & 346 & & 0.497 & & .705 & \\
\hline
\end{tabular}

Table 4. Effect of Pomegranate molasses on yolk color at 0, 10, 20 and 30 days of storage

\begin{tabular}{|c|c|c|c|c|c|c|c|c|c|}
\hline \multirow[t]{2}{*}{ Group } & \multicolumn{2}{|c|}{$0^{\text {th }}$ day } & \multicolumn{2}{|c|}{$10^{\text {th }}$ day } & \multicolumn{2}{|c|}{$20^{\text {th }}$ day } & \multicolumn{2}{|c|}{$30^{\text {th }}$ day } & \multirow[t]{2}{*}{$\mathrm{p}$} \\
\hline & $\overline{\bar{X}}$ & SEM & $\overline{\bar{X}}$ & SEM & $\overline{\bar{X}}$ & SEM & $\overline{\bar{X}}$ & SEM & \\
\hline A & $12.750^{\mathrm{ab}}$ & 0.2189 & $13.344^{b}$ & 0.2027 & 12.656 & 0.1921 & 13.187 & 0.1700 & 0.318 \\
\hline B & $12.125^{\mathrm{a}}$ & 0.3461 & $12.969^{a b}$ & 0.1736 & 12.875 & 0.1963 & 12.875 & 0.3146 & 0.084 \\
\hline $\mathrm{C}$ & $12.406^{a b}$ & 0.2709 & $13.000^{\mathrm{ab}}$ & 0.2092 & 12.781 & 0.2457 & 12.906 & 0.3169 & 0.406 \\
\hline D & $13.219^{\mathrm{Bb}}$ & 0.1706 & $12.281^{\mathrm{Aa}}$ & 0.1644 & $13.031^{\mathrm{AB}}$ & 0.2014 & $13.469^{\mathrm{B}}$ & 0.1852 & 0.001 \\
\hline $\mathrm{E}$ & $12.656^{\mathrm{Aab}}$ & 0.1563 & $12.562^{\mathrm{Aa}}$ & 0.1819 & $13.187^{\mathrm{B}}$ & 0.1760 & $13.594^{\mathrm{B}}$ & 0.1838 & 0.001 \\
\hline$P$ & & & & & & & & & \\
\hline
\end{tabular}

Table 5. Effect of Pomegranate molasses on Haugh Unit at 0,10,20 and 30 days of storage

\begin{tabular}{|c|c|c|c|c|c|c|c|c|c|}
\hline Group & \multicolumn{2}{|c|}{$0^{\text {th }}$ day } & \multicolumn{2}{|c|}{$10^{\text {th }} \mathrm{day}$} & \multicolumn{2}{|c|}{$20^{\text {th }}$ day } & \multicolumn{2}{|c|}{$30^{\text {th }}$ day } & $\mathrm{p}$ \\
\hline & $\overline{\bar{X}}$ & SEM & $\overline{\bar{X}}$ & SEM & $\overline{\bar{X}}$ & SEM & $\overline{\bar{X}}$ & SEM & \\
\hline A & 86.613 & 2.2182 & $83.175^{\mathrm{ab}}$ & 2.4428 & 84.909 & 1.7575 & 87.516 & 1.3208 & 0.296 \\
\hline B & $92.624^{\mathrm{B}}$ & 1.4553 & $85.269^{\mathrm{Aab}}$ & 1.7388 & $85.383^{\mathrm{A}}$ & 1.2128 & $84.769^{A}$ & 1.6554 & 0.002 \\
\hline $\mathrm{C}$ & 88.938 & 1.5555 & $84.630^{\mathrm{ab}}$ & 1.6822 & 84.315 & 1.7763 & 85.633 & 1.4148 & 0.129 \\
\hline $\mathrm{D}$ & $86.968^{\mathrm{AB}}$ & 1.8400 & $88.951^{\mathrm{Bb}}$ & 1.6551 & $82.134^{\mathrm{A}}$ & 2.2285 & $86.814^{\mathrm{AB}}$ & 1.4201 & 0.029 \\
\hline $\mathrm{E}$ & 86.636 & 1.9472 & $79.998^{a}$ & 2.3444 & 85.725 & 1.0874 & 88.529 & 2.2252 & 0.130 \\
\hline$P$ & \multicolumn{2}{|c|}{0.113} & \multicolumn{2}{|c|}{0.036} & \multicolumn{2}{|c|}{0.496} & \multicolumn{2}{|c|}{0.563} & \\
\hline
\end{tabular}


Table 6. Effect of Pomegranate molasses on eggshell thickness at 0,10,20 and 30 days of storage

\begin{tabular}{|c|c|c|c|c|c|c|c|c|c|}
\hline \multirow[t]{2}{*}{ Group } & \multicolumn{2}{|c|}{$0^{\text {th }}$ day } & \multicolumn{2}{|c|}{$10^{\text {th }}$ day } & \multicolumn{2}{|c|}{$20^{\text {th }}$ day } & \multicolumn{2}{|c|}{$30^{\text {th }}$ day } & \multirow[t]{2}{*}{$\mathrm{P}$} \\
\hline & $\overline{\bar{X}}$ & SEM & $\bar{X}$ & SEM & $\overline{\bar{X}}$ & SEM & $\overline{\bar{X}}$ & SEM & \\
\hline A & 0.363 & 0.01011 & 0.379 & 0.006612 & 0.371 & 0.007663 & 0.369 & 0.005039 & 0.465 \\
\hline B & 0.361 & 0.006612 & 0.380 & 0.006831 & 0.381 & 0.008004 & 0.368 & 0.009627 & 0.221 \\
\hline C & 0.371 & 0.008778 & 0.358 & 0.007201 & 0.367 & 0.007344 & 0.359 & 0.01076 & 0.631 \\
\hline D & 0.379 & 0.009463 & 0.380 & 0.009083 & 0.391 & 0.01074 & 0.364 & 0.01060 & 0.278 \\
\hline $\mathrm{E}$ & 0.388 & 0.005261 & 0.382 & 0.008427 & 0.388 & 0.009408 & 0.374 & 0.01144 & 0.598 \\
\hline$P$ & & & & & & & & & \\
\hline
\end{tabular}

Table 7. Effect of Pomegranate molasses on albumin index at 0, 10, 20 and 30 days of storage

\begin{tabular}{|c|c|c|c|c|c|c|c|c|c|}
\hline \multirow[t]{2}{*}{ Group } & \multicolumn{2}{|c|}{$0^{\text {th }}$ day } & \multicolumn{2}{|c|}{$10^{\text {th }}$ day } & \multicolumn{2}{|c|}{$20^{\text {th }}$ day } & \multicolumn{2}{|c|}{$30^{\text {th }}$ day } & \multirow[t]{2}{*}{$\mathrm{P}$} \\
\hline & $\overline{\bar{X}}$ & SEM & $\overline{\bar{X}}$ & SEM & $\overline{\bar{X}}$ & SEM & $\overline{\bar{X}}$ & SEM & \\
\hline A & 9.013 & 0.4927 & 8.404 & 0.4271 & 8.416 & 0.4119 & 9.234 & 0.3624 & 0.332 \\
\hline B & $10.539^{\mathrm{B}}$ & 0.5069 & $8.566^{\mathrm{A}}$ & 0.6147 & $8.727^{\mathrm{A}}$ & 0.3952 & $8.528^{\mathrm{A}}$ & 0.4100 & 0.009 \\
\hline $\mathrm{C}$ & 9.687 & 0.5003 & 8.747 & 0.4742 & 8.443 & 0.3615 & 9.394 & 0.4038 & 0.092 \\
\hline $\mathrm{D}$ & 8.863 & 0.4698 & 9.615 & 0.4802 & 8.763 & 0.5486 & 9.386 & 0.5020 & 0.407 \\
\hline $\mathrm{E}$ & 8.876 & 0.5714 & 7.629 & 0.5320 & 8.628 & 0.2665 & 9.405 & 0.5190 & 0.062 \\
\hline$P$ & \multicolumn{2}{|c|}{0.087} & \multicolumn{2}{|c|}{0.064} & \multicolumn{2}{|c|}{0.967} & \multicolumn{2}{|c|}{0.574} & \\
\hline
\end{tabular}

Table 8. Effect of Pomegranate molasses on yolk index at 0,10,20 and 30 days of storage

\begin{tabular}{|c|c|c|c|c|c|c|c|c|c|}
\hline \multirow[t]{2}{*}{ Group } & \multicolumn{2}{|c|}{$0^{\text {th }}$ day } & \multicolumn{2}{|c|}{$10^{\text {th }}$ day } & \multicolumn{2}{|c|}{$20^{\text {th }}$ day } & \multicolumn{2}{|c|}{$30^{\text {th }}$ day } & \multirow[t]{2}{*}{$\mathrm{p}$} \\
\hline & $\bar{X}$ & SEM & $\bar{X}$ & SEM & $\bar{X}$ & SEM & $\bar{X}$ & SEM & \\
\hline A & $41.549^{\mathrm{Aab}}$ & 0.6374 & $41.532^{\mathrm{Aa}}$ & 0.5949 & $42.864^{\mathrm{AB}}$ & 0.7364 & $45.228^{\mathrm{B}}$ & 0.8922 & 0.001 \\
\hline B & $43.483^{\mathrm{Ab}}$ & 0.6791 & $41.679 \mathrm{Aa}$ & 0.5469 & $42.018^{\mathrm{A}}$ & 0.7639 & $46.745^{\mathrm{B}}$ & 0.7562 & 0.001 \\
\hline C & $41.621^{\mathrm{Aab}}$ & 0.4060 & $41.519 \mathrm{Aa}$ & 0.5342 & $41.827^{\mathrm{A}}$ & 0.6695 & $44.507^{B}$ & 0.8972 & 0.007 \\
\hline $\mathrm{D}$ & $40.422^{\mathrm{Aa}}$ & 0.5347 & $39.975^{\mathrm{Ab}}$ & 0.6186 & $42.591^{\mathrm{AB}}$ & 0.8178 & $44.463^{\mathrm{B}}$ & 0.8698 & 0.001 \\
\hline $\mathrm{E}$ & $41.826^{\mathrm{Aab}}$ & 0.7131 & $39.603^{\mathrm{Ab}}$ & 0.6515 & $43.854^{\mathrm{AB}}$ & 1.0322 & $45.455^{\mathrm{B}}$ & 0.7185 & 0.001 \\
\hline$P$ & \multicolumn{2}{|c|}{0.015} & \multicolumn{2}{|c|}{0.031} & \multicolumn{2}{|c|}{0.489} & \multicolumn{2}{|c|}{0.294} & \\
\hline
\end{tabular}

\section{DISCUSSION}

According to (Dei et al. 2008) average daily gain (ADG) was increased by treatment of pomegranate molasses and no effect is seen on water intake (Shabtay et al. 2008). In contrast to this (Saki et al. 2014a) had observed no positive impact on FCR, feed intake, egg weight and egg mass in layers hens. Previous researchers observed that using thyme and oregano in the ration of laying hens positively increase the egg mass and egg weight with the supplementation of thyme and oregano (AbdelWareth et al. 2013). However, other studies did not find any positive results on egg weight with the supplementation of herbs in the diet of Laying Japanese Quails (Christaki et al. 2011). (Rahman et al. 2017) study indicated that supplementation of Mentha Piperita oil and its juice in the laying hen's diet had no significant effect on egg quality traits during storage for 15 and 30 days at $4^{\circ} \mathrm{C}$. Similarly, in another study, no significant loss of egg weight was observed at $5^{\circ} \mathrm{C}$ and $21^{\circ} \mathrm{C}$ temperature till 10 days in normal fed diet layers hens (Jin et al. 2011). Similarly, the recent study showed that there was no significant effect $(\mathrm{p}>0.05)$ on egg weight during the whole study period.

Some researchers observed that with supplementation of $5 \%$ carrots in the diet of laying hen increased egg yolk color however, Haugh unit, eggshell thickness, and egg shape index remained unaffected (Ishikawa et al. 1999). For egg yolk, supplementation of $70 \mathrm{~g} / \mathrm{day}$ purple carrots increased egg yolk index. Moreover, purple carrots showed positive affect on egg yolk (Hammershøj et al. 2010). However, in our study the egg yolk color was significant between the groups at zero day storage and after ten day egg storage analysis, yolk color was increased significantly and egg yolk color was significantly increased at twenty and thirty day egg storage analysis within the $1 \mathrm{mg} / \mathrm{L}$ and $2 \mathrm{mg} / \mathrm{L}$ pomegranate molasses groups as compared to the control group.

Dietary supplementation of pomegranate molasses had no positive affect on the egg quality parameters such as the egg shell thickness, Haugh unit, eggshell weight, eggshell breaking strength. (Saki et al. 2014a) Some of the researcheres like (Navid et al. 2014) reported non-significant impact on egg quality trait of 
plant extracts. Similarly in our research trial the Haugh unit was decreased significantly between the groups at 10 day storage analysis as compared to zero day analysis and it was also decreased during 30 day storage analysis within the groups of $0.25 \mathrm{mg} / \mathrm{L}$ and $1.0 \mathrm{mg} / \mathrm{L}$. Moreover, egg shell thickness also remained non-significant during the whole trial of egg analysis. Feeding laying hen with pomegranate pulp had no positive result on yolk and albumen indexes and also Haugh unit was remained non-affected by dietary treatments, which could confirm the low effect of nutrition on Haugh unit (Saki et al. 2014c) In our study, egg albumin index was decreased significantly within the $0.25 \mathrm{mg} / \mathrm{L}$ of pomegranate molasses juice group. However, it was remained non-significant in all other supplemented groups over control. Similarly, a good effect was observed on the yolk index within the groups and between the groups and the yolk index was increased between the groups at zero day and 10 day storage analysis and yolk index was increased in group $0.25 \mathrm{mg} / \mathrm{L}$ and also increased within all groups at thirty day of analysis.

\section{CONCLUSION}

In conclusion, Pomegranate molasses had no effect on egg weight, egg shell breaking strength and eggshell thickness while positive affect was observed effect on yolk color, albumin index and Haugh unit. Overall, pomegranate molasses supplementation was found beneficial to preserve the egg texture and quality. It was suggested to do more research on egg external and internal parameters after storage for prolonged duration at relatively higher temperature.

\section{ACKNOWLEDGEMENT}

The current study was performed at the Experimental Animal Research farm of Afyon Kocatepe University, Turkey after the approval of the Local Ethics Committee of the faculty of veterinary medicine under approval No: AKÜHADYEK146-16, on 03-01-2016.

\section{REFERENCES}

Abdel-WA, Ismail ZSH, Sudekum K. Effects of thyme and oregano on performance and egg quality characteristics of laying hens. Worlds. Poult. Sci. J. 2013;69(1): 1-7.

Ahn DU, Sell JL., Jo C. Chamruspollert, M., \& Jeffrey, M. Effect of dietary conjugated linoleic acid on the quality characteristics of chicken eggs during refrigerated storage. Poultry Science, 1999;78(6), 922-928.

Angerosa F, d'Alessandro N, Corana F, Mellerio G. Characterization of phenolic and secoiridoid aglycons present in virgin olive oil by gas chromatographychemical ionization mass spectrometry. Journal of Chromatography A, 1996; 736(1-2), 195-203.

Christaki EV, Bonos EM, Florou-Paneri PC. Comparative evaluation of dietary oregano, anise and olive leaves in laying Japanese quails. Brazilian Journal of Poultry Science, 2011;13(2), 97-101.
Dei HK, Rose SP, Mackenzie AM, Amarowicz R. Growth performance of broiler chickens fed diets containing shea nut (Vitellaria paradoxa, Gaertn.) meal fermented with Aspergillus niger. Poult. Sci. 2008;87(9): 1773-8.

Ezra D, Gat T, Skovorodnikova Y, Vardi Y, Kosto I. First report of Alternaria black spot of pomegranate caused by Alternaria alternata in Israel. Australas. Plant Dis. Notes. 2010;5(1): 1-2.

Gunal M, Yayli G, Kaya O, Karahan N, Sulak O. The effects of antibiotic growth promoter, probiotic or organic acid supplementation on performance, intestinal microflora and tissue of broilers. Int. J. Poult. Sci. 2006;5(2): 149-55.

Guo FC, Kwakkel RP, Williams BA. Effects of mushroom and herb polysaccharides on cellular and humoral immune responses of Eimeria tenella-infected chickens. Poult. Sci. 2004;83(7): 1124-32.

Gultepe EE. Bayram I. IQBAL A. Revista Brasileira de Zootecnia Effects of Pistacia terebinthus seed meal and different storage times on egg quality of laying hens. 2018.

Hammershøj M, Kidmose U, Steenfeldt S. Deposition of carotenoids in egg yolk by short-term supplement of coloured carrot (Daucus carota) varieties as forage material for egg-laying hens. J. Sci. Food Agric. 2010;90(7): 1163-71.

İshıkawa S, Murakamı, H, Yamazakı, M, Takemasa, M. Effect of Carrot Leaf Supplementation on Egg Yolk $\beta$ Carotene Content and Egg Quality. Japanese poultry science, 1999;36(4), 275-283.

Jin YH, Lee KT, Lee WI, Han YK. Effects of storage temperature and time on the quality of eggs from laying hens at peak production. Asian-Australasian Journal of Animal Sciences, 2011;24(2), 279-284.

Khan RU, Nikousefat Z, Tufarelli V, Naz S. Garlic (Allium sativum) supplementation in poultry diets: Effect on production and physiology. Worlds. Poult. Sci. J. 2012;68(3): 417-24.

Lansky P, Schilcher, H. P, J.D., Loew D. Plants that lower cholesterol. First World Congr. Med. Aromat. Plants Hum. welfare, Maastricht, Netherlands, Acta- Hortic. 1993. p. 131-136.

Manterys A, Franczyk ZM, Czyzynska CI. Haematological parameters, serum lipid profile, liver function and fatty acid profile of broiler chickens fed on diets supplemented with pomegranate seed oil and linseed oil. Br. Poult. Sci. 2016;57(6): 771-9.

Miguel, G, Fontes C, Antunes ., Neves A, Martins D. Anthocyanin concentration of "Assaria" pomegranate fruits during different cold storage conditions. BioMed Research International, 2004(5), 338-342.

National Research Council. Nutrient Requirements of Poultry: Ninth Revised Edition, 1994. Natl. Acad. Press. 1994.

Navid J, Mozaffar M, Kazem K. Effect of dietary medicinal herbs on performance, egg quality and immunity response of laying hens. Adv. Environ. Biol. 2014;7(13): 4382-9.

Özkal N, Dinç S: Nar Meyvesinin Kimyasal Bileşimi Ve Biyolojik Aktiviteleri. Ankara Eczacllke Fakültesi Dergisi, 1993, 22: 1-2.

Rahimi S, Teymouri Z, Karimi TMA, Omidbaigi R, Rokni H. Effect of the three herbal extracts on growth performance, immune system, blood factors and intestinal selected bacterial population in broiler chickens. J. Agric. Sci. Technol. 2011;13(4): 527-39. 
Rahman A, Eren GE, Uyarlar C, Cetıngul S, Iqbal A , Bayram I. Effect of Mentha Piperita (Peppermint) Extract and its Juice on Egg Quality Traits during Different Storage Time in Laying Hens. Kocatepe Vet. J. Kocatepe Vet J Kocatepe Vet J. 2017;10(101): 14-20.

Kalita D, Jayanty SS. Comparison of polyphenol content and antioxidant capacity of colored potato tubers, pomegranate and blueberries. Journal of Food Processing \& Technology, 2014 5(8), 1.

Saki AA, Aliarabi H, Hosseini SA, Salari J, Hashemi M. Effect of a phytogenic feed additive on performance, ovarian morphology, serum lipid parameters and egg sensory quality in laying hen. Vet. Res. forum an Int. Q. J. 2014a;5(4): 287-93.

Saki AA, RM, Zamani P, Yousefi A. The Effects of Different Levels of Pomegranate Seed Pulp with Multi Enzyme on Performance, Egg Quality and Serum Antioxidant in Laying Hens. 2014b;4(May): 803-8.

Saki AA, Rabet M, Zamani P, Yousefi A. The Effects of Different Levels of Pomegranate Seed Pulp with Multi Enzyme on Performance, Egg Quality and Serum Antioxidant in Laying Hens. Iran. J. Appl. Anim. Sci. 2014c;4(4): 803-8.

Samli HE, Agma A, Senkoylu N. Effects of Storage Time and Temperature on Egg Quality in Old Laying Hens. Poult. Sci. 2005;14(1): 548-53.

Scott ML, Hull SJ, Mullenhoff PA. The calcium requirements of laying hens and effects of dietary oyster shell upon egg shell quality. Poult. Sci. [Internet]. 1971;50(4): 1055-63. Available from: http://ps.oxfordjournals.org/content/50/4/1055.abstrac $\mathrm{t}$

Shabtay A, Eitam H, Tadmor Y, Orlov A, Meir A, Kerem Z. Nutritive and antioxidative potential of fresh and stored pomegranate industrial byproduct as a novel beef cattle feed. J. Agric. Food Chem. 2008;56(21): 10063-70.

Yılmaz B, Usta Ç. Nar'ın (Punica granatum) terapötik etkileri. Türkiye Aile Hekimliği Dergisi 2010; 14: 146-53.

Williams KC. Some factors affecting albumen quality with particular reference to Haugh unit score. Worlds. Poult.Sci.J.1992;48(01):5-16.Availablefrom: http://www.journals.cambridge.org/abstract_S00439339 92000023

Windisch W, Schedle K, Plitzner C, Kroismayr A. Use of phytogenic products as feed additives for swine and poultry. J. Anim. Sci. 2008;86(14): E140-8.

Wu J, Jahncke ML, Eifert JD, O'Keefe SF, Welbaum GE. Pomegranate peel (Punica granatum L) extract and Chinese gall (Galla chinensis) extract inhibit Vibrio parahaemolyticus and Listeria monocytogenes on cooked shrimp and raw tuna. Food Control. Elsevier Ltd; 2016;59: 695-9. Available from: http://dx.doi.org/10.1016/j.foodcont.2015.06.050 